\title{
As danças populares na obra de Mário de Andrade
}

\section{The folkloric dances in Mário de Andrade’s work}

\author{
Roberta Cristina de Paula \\ Mestre pela Faculdade de Educação da Unicamp, professora da rede pública \\ municipal de Campinas e integrante do Grupo de Teatro e Danças \\ Populares Urucungos, Puítas e Quijengues, de Campinas - SP \\ rodepaula@hotmail.com
}

\section{Resumo:}

Este estudo tem como objetivo analisar as danças na obra do escritor modernista Mário de Andrade. Para realizar tal pesquisa tomo como base, principalmente, dois textos da extensa obra do autor: $O$ Turista Aprendiz e Danças Dramáticas do Brasil, pois a partir das respectivas leituras, pude ampliar conhecimentos referentes ao universo das manifestaçóes populares brasileiras, especificamente as danças.

Palavras-chave: Danças populares;

Literatura; Mário de Andrade
Abstract:

This study aims to analyze the dances in Mário de Andrade's work, a modernist writer. To conduct this research, I take as reference, mainly two texts from the extensive work of the author: $\mathrm{O}$ Turista Aprendiz and Danças Dramáticas do Brasil. From the respective readings, I could expand knowledge concerning of the universe of Brazilian popular manifestations, specifically, the dances.

Keywords: Folk dances; Literature; Mário de Andrade 
Segundo Luckacs, as obras são revitalizadas pelo tempo, desde que possam responder as ânsias semelhantes às do periodo em que foram produzidas.

1 - Este artigo baseia-se em minha dissertação de mestrado, intitulada: "Quem foi que disse que não vivo satisfeito? Eu danço!" Encontros com as danças na obra de Mário de Andrade (PAULA, 2012), defendida em 31/08/2012 na Faculdade de Educação da Unicamp, tendo como orientadora a professora doutora Elisa Angotti Kossovitch.

2 - Grupo de teatro e danças populares Urucungos, Puítas e Quijengues, Campinas- SP, criado em 1988 pela professora Raquel Trindade.

3-O termo danças populares relaciona-se aqui às manifestações realizadas, prioritariamente, em contextos de grupos, agremiações e comunidades que as perpetuam de geração em geração. $O$ aprendizado delas se dá na coletividade, havendo participação de pessoas de diferentes idades.

4 - Faz-se necessário ressaltar que, de acordo com Santos (2010), o termo danças dramáticas não foi inventado por Andrade, uma vez que já aparecera na obra do antropólogo inglês William Ridegway, "The Dramas and Dramatic Dances of the Non- European Races", em 1915.
Telê Ancona Lopez

$\mathrm{F}$ oi a partir da minha trajetória pessoal que surgiu o interesse em aprofundar-me no campo das danças populares brasileiras, primeiramente de forma exploratória e mais tarde academicamente, através da pesquisa.[1] Isto porque, no início da década de 1990, passei a integrar um grupo de danças populares[2], participando de vivências que possibilitaram com que passasse a discutir a linguagem corporal enquanto mais uma importante forma de expressão dos sujeitos.

Iniciei o mestrado em 2009, com o intuito de analisar o espaço ocupado pelas manifestaçóes populares nas práticas escolares, uma vez que reconhecia tais instituiçôes como redutos que acabam por limitar o acesso ao conhecimento privilegiando a linguagem verbal, seja ela escrita ou oral; entretanto, com o decorrer do processo de pesquisa houve uma reavaliação dos objetivos, o que ocasionou na mudança do objeto de estudo. Assim, as danças, que teriam um papel secundário dentro da primeira proposta, passaram a ser o objeto central.

Até então, Mário de Andrade já constava das minhas referências bibliográficas, pois como bem coloca Conrado (2004): "Numa breve retrospectiva, lembramos alguns nomes que fizeram registros importantes sobre as danças e manifestaçóes populares brasileiras e servem de referência até a contemporaneidade: Mário de Andrade, Arthur Ramos, Renato Almeida, Oneida Alvarenga, Câmara Cascudo,.... Todavia, foi a partir da leitura d'O Turista Aprendiz (1976)que fui identificando elementos que ao longo da pesquisa foram cada vez mais proporcionando com que construísse novos olhares para com o universo em questão; também, por intermédio d'O Turista, é que passei a ressignificar o papel desempenhado pelas danças populares brasileiras [3] enquanto elementos de identidade para determinados grupos sociais.

Já no segundo texto destacado, Danças Dramáticas do Brasil (1982), encontrei uma frase emblemática para o processo em curso. Esta frase finaliza o texto introdutório: As danças dramáticas do Brasil, diz: "Da maneira como as coisas vão indo, a sentença é de morte”. Ela explicita o pensamento de Mário de Andrade, naquele período (década de 1930, início dos anos de 1940), frente às várias limitaçóes impostas às realizaçóes de ensaios e apresentaçóes de agremiaçóes que cultuavam danças dramáticas. Sobre este termo dizia que:

Reúno sob o nome genérico de "danças dramáticas" não só os bailados que desenvolvem uma ação dramática propriamente dita, como também os bailados coletivos que, junto com obedecerem a um tema dado tradicional e caracterizador, respeitam o princípio formal da Suíte, isto é, obra musical constituída pela seriação de várias peças coreográficas[4]. (ANDRADE, 1982a: 71)

Para a produção das reflexôes e análises ao longo da pesquisa amparei-me no 
conceito de homo ludens de Huizinga (1971); em seu estudo, o objeto é o jogo como elemento da cultura, ocupando desta forma uma funçáo social; por sua vez, sendo a dança também compreendida como jogo, tem ela um significado e função social. Para o historiador: "A dança é uma forma especial e especialmente perfeita do próprio jogo" (HUIZINGA, 1971: 184).

Outro teórico no qual embasei as ideias esboçadas foi Bakhtin (1999), sendo que a referida obra também discute a dimensão da cultura popular, analisa o espaço ocupado pelas manifestaçóes populares na vida dos homens da Idade Média, enfatizando o carnaval como representante da segunda vida do povo, possibilitando a manifestação da vida festiva, do riso, da dimensão humana lúdica, e por fim, da ressignificação das identidades.

Quando me refiro às danças populares não restrinjo esses eventos ao período carnavalesco, mas ressalto essa época como um momento propício para a manifestaçâo das mesmas. Sabe-se, no entanto, que tais acontecimentos ultrapassam determinados períodos, assim encontram-se, muitas vezes, presentes no cotidiano de grupos e comunidades.

Partindo das respectivas leituras, realizei pesquisa documental nos acervos históricos da Sociedade de Etnografia e Folclore (SEF), e da Missão de Pesquisas Folclóricas (MPF), ambos pertencentes à Discoteca Oneida Alvarenga, localizada no Centro Cultural São Paulo (CCSP), vinculado à Secretaria de Cultura de São Paulo. Outra fonte primária utilizada foi o levantamento dos registros fotográficos que representam a presença das danças[5], com destaque para os bailados tradicionais, nos Parques Infantis de Sáo Paulo (PIs), instituiçóes vinculadas ao Departamento de Cultura de São Paulo (DCSP), através da Divisão de Educação e Recreio.

A criação da SEF, a realização do projeto da MPF e a implementação de atividades artísticas e culturais nos programas dos PIs foram açóes ocorridas no período de 1935-38, anos em que Mário de Andrade esteve na direção do Departamento de Cultura de São Paulo (DCSP). Tais iniciativas atestam o empenho do pesquisador, homem público, que priorizou tanto a pesquisa quanto o desenvolvimento de políticas que favorecessem a disseminação dos conhecimentos acumulados.

Para estabelecer um diálogo com a contemporaneidade, buscando-se uma análise relacionada aos aspectos que caracterizam as transformaçóes, desaparecimentos e continuidades das tradiçóes, trouxe como interlocutores dois pesquisadores da obra de Mário de Andrade: Luiz Adriano Daminello[6] e Amarildo Carnicel[7]; além da mestra de danças populares Raquel Trindade.

Afirmo que as pesquisas e os estudos sobre a obra de Mário de Andrade são vários, sejam eles relacionados à produção literária, à música popular, ao período em que foi diretor do DCSP, à fotografia, às correspondências trocadas com vários amigos (as); porém, chamou-me a atenção, no levantamento bibliográfico, ter encontrado poucos títulos que tratassem especificamente das danças. Admito que, música e dança populares são elementos que se articulam, complementares, inextricáveis, no entanto, ressalto que, falar dos cabocolinhos, do bumba meu boi, da ciranda, do samba rural paulista, das cheganças, da congada, e outras manifestaçóes, com ênfase da dimensão humana lúdica, do papel que essas desempenham na construção das identidades dos brincantes, e dos seus grupos sociais, enfatizando a linguagem corporal, é propor outro enfoque a este universo.

Com isso, por considerar que o universo das danças populares proporciona o acesso a uma arte e a uma estética fabulosas, realizei o mergulho na obra de Mário de Andrade, objetivando ampliar os conhecimentos dessas culturas, fomentando novos diálogos.
5 - O período delimitado foi de 1935-38.

6 - Diretor do documentário: Mário e a Missão (MÁRIO, 2003).

7 - Autor do livro: O Fotógrafo Mário de Andrade (CARNICEL, 1994). 
8 - Em 1924 Mário de Andrade participou da viagem às Minas Gerais, que ficou conhecida como A viagem da descoberta do Brasil, na companhia de Oswald de Andrade, Tarsila do Amaral e de Blaise Cendrars.
9 - Mário de Andrade se referia ao norte e sul do país, sendo que o norte compreendia as regiões norte e nordeste; o sul as regiões sul e sudeste.

\section{AS VIAGENS ETNOGRÁFICAS}

Foi entre os anos de 1927-29 que Mário de Andrade realizou as suas viagens etnográficas às regiôes norte e nordeste do país. O interesse por essas incursóes pelo interior do território brasileiro acompanhava-o desde o início dos anos de 1920[8], pois mesmo sendo um homem que pouco viajava, era um assíduo correspondente, tinha vários amigos com os quais trocava cartas e através delas coletava várias informações relacionadas às culturas populares. Conforme comenta Lopez:

É assim que a valorização do nacional já começa a existir para o jovem professor do Conservatório Dramático e Musical de São Paulo, quando, por volta de 1921, recolhe documentos populares como pregóes, parlendas, paródias cantadas, cantigas de roda, em sua cidade e circunvizinhanças, registrando-os cuidadosamente. Já começa a existir para o paulistano que gosta de escrever e que, em férias na "chacra do tio Pio", em Araraquara, absorve atentamente as narrativas populares da zona do Moji. (in ANDRADE, 1976: 15)

Tal interesse fica perceptível quando se acompanha a sua produção poética nesta mesma década; observa-se a presença de elementos das culturas populares e também o desejo por conhecer outros Brasis, caracterizando o projeto do intelectual que era a construçáo de uma identidade nacional, referendada no universo popular.

Mas foram as suas viagens etnográficas que resultaram na publicação dos dois textos póstumos, que priorizei nesta pesquisa. $\mathrm{O}$ turista aprendiz, que foi a reunião dos relatos dos diários de ambas as viagens, apresentando assim uma leitura onde se identifica muito das percepçóes do poeta, do homem apaixonado, mas nem por isso menos crítico, das diferentes realidades brasileiras. Evidencia-se a sua admiração, encantamento ao encontrar-se com tantas manifestaçóes populares. Em Danças Dramáticas do Brasil, fica registrada a determinação em documentar detalhadamente os bailados que presenciou, mapeando suas origens, apresentando seus históricos e as referências africanas, ameríndias e ibéricas ligadas a elas.

$\mathrm{O}$ intelectual considerava que era no norte e nordeste do Brasil que ainda se preservava o tesouro de nossas culturas populares, pois aqui no sul[9] muito já havia se perdido, esquecido, transformado, devido às influências europeias, e o processo de industrialização pelo qual passava o país.

A primeira viagem etnográfica aconteceu de maio a agosto de 1927, centrando-se na regiâo norte. Escolheu este período por concentrarem-se aí várias apresentaçóes de danças dramáticas. Entretanto, analisando os relatos de viagem, constata-se que não houve uma preocupação em registrar sistematicamente tudo o que pôde presenciar. Porém, pela sua narrativa, se tem o prazer de "viajar" por cidades, lugarejos; "assistir" aos ensaios, apresentaçóes de danças; "conversar" com personagens cativantes; "experimentar" sensaçóes; "saborear" pratos exóticos, enfim, também aventurar-se com o turista aprendiz. Segundo Lopez:

A viagem à Amazônia, a julgar-se pelos textos de 1927 e 1928 que dela resultaram, foi claramente marcada pela preocupação etnográfica, com Mário de Andrade procurando entender uma particularidade do Brasil através da obser- 
vação da vida do povo. Ela teria também lhe mostrado a necessidade de pôr logo em prática seu velho projeto de visita ao Nordeste, desejando agora realizar uma pesquisa mais sistemática em uma região que se oferecia tão rica em tradição musical popular. (in ANDRADE, 1976: 19)

Seria em dezembro de 1928 que Mário de Andrade partiria para a sua segunda viagem etnográfica, dessa vez tendo como foco a regiáo nordeste. Os estados visitados foram: Bahia, Alagoas, Pernambuco, Rio Grande do Norte e a Paraíba; contatando alguns de seus amigos, dentre eles: Ascenso Ferreira, Cícero Dias e Câmara Cascudo. Esta excursão, que foi até fevereiro de 1929, possibilitou com que o pesquisador colhesse uma imensa gama de materiais, sendo registros de cantigas populares; toadas de danças dramáticas- letras e partituras; realizando também registros fotográficos. A maior parte dos documentos recolhidos refere-se aos estados da Paraíba e do Rio Grande do Norte.

Sobre esta viagem, Batista escreveu que: "Desembarca no Rio de Janeiro a 24 de fevereiro de 1929, trazendo - segundo Oneida Alvarenga - uma colheita impressionante desses três meses no Nordeste: cerca de 1500 documentos musicais grafados à mão" (BATISTA, 2004: 36). É justamente tais documentos que comporão a maior parte dos três volumes de Danças Dramáticas do Brasil, obra póstuma, organizada por sua discípula Oneida Alvarenga.

Durante os três meses de pesquisa, Mário de Andrade, por intermédio de amigos, consegue manter contato com músicos, cantadores, dançarinos, conhecedores de diversas manifestaçóes. São sujeitos, homens e mulheres, colaboradores (as) que o turista fez questão de identificar e descrever em seus trabalhos. Ressalto este aspecto da pesquisa, pois muitas vezes percebe-se no trato com este campo a ausência de referências, isto é, por serem culturas populares são identificadas como de domínio público, assim há um anonimato da (s) pessoa (s), no entanto, são mantidas, transmitidas e vivenciadas por determinados sujeitos, homens, mulheres, meninos e meninas.

O trabalho desenvolvido na segunda viagem resultou no registro das seguintes danças: as Cheganças; os Pastoris; os Congos; o Maracatu; os Cabocolinhos; o Bumba-meu-boi[10]. Foram registrados além das toadas- letras e partituras, as personagens presentes nas danças, os instrumentos característicos, também compondo o texto, uma pesquisa histórica das respectivas manifestaçóes. Observa-se o incansável trabalho de Mário de Andrade com o intuito de aprofundar os conhecimentos sobre cada bailado.

Destaco a admirável narrativa do pesquisador que incorpora suas impressóes, faz relaçóes até mesmo com danças originárias de outras culturas, ultrapassando uma descrição formal. Exemplo disso é quando fala sobre um ensaio de Cabocolinhos que assistiu em 5/2/1929:

10 - Importante salientar que no terceiro volume de Danças Dramáticas do Brasil encontram-se as Congadas e o Moçambique, sendo elas resultadas de pesquisas desenvolvidas no estado de São Paulo, cf. ANDRADE, 1982c, p.196267.

... Depois fomos no bairro de Cruz de Alma, de operários, ver um ensaio de Cabocolinhos. Formidável coreografia bruta. Mistura de instintos primitivos estonteante, com a monotonia formidável de gaita, bombo e ganzá. Coisas africanas, ameríndias, incaicas e russas. Na dança "do sapo" é fato que o passo russo táo conhecido de ficar de cócoras com uma das pernas estendidas, e pular, estendendo a outra e cruzando a primeira, estava executado. Saí 
11 - Brincante é o termo que se refere aos sujeitos que participam dos folguedos populares, sejam eles (as) tocadores (as), dançarinos (as), cantores (as). Cf. BENJAMIN, 1989.

12 - Importante colocar que o mesmo não era ligado ao grupo de intelectuais modernistas; antes $d a$ criação do DCSP já coordenava os Parques Infantis da cidade, cf. RAFFAINI, 2001, p. 40.

13 - Instituições vinculadas à Divisão de Educação e Recreio. Destaco a importante pesquisa de Faria (2002) que apresenta estas instituições como uma referência para a elaboração de políticas, na atualidade, para a primeira etapa da educação básica.

14 -Ressalto também a afirmação de Raffaini que a proposta dos PIs se estruturava no binômio saúde e educação, uma vez que eram voltados para crianças das classes populares, havia uma grande preocupação sanitarista, cf. RAFFAINI, 2001, p.66. besta da sala apertada do clube, um calorão pavoroso e o cheiro dos corpos suados que na dança de despedida, dançando então todos admiravelmente foram tomados dum frenesi dionisíaco espantoso. Saí besta, não tem dúvida. (ANDRADE, 1982b: 180) [grifos meus]

Mário de Andrade tinha como um dos seus objetivos a publicação de uma obra que reunisse o maior número das nossas manifestaçóes populares, que receberia o nome de $\mathrm{Na}$ pancada do ganzá, entretanto isso não se concretizou.

Primeiramente, com a leitura d'O Turista Aprendiz, e num segundo momento através das Danças Dramáticas é que fui me familiarizando com a obra, por proporcionar com que identificasse descriçóes das danças e versos dos cantos os quais já conhecia, seja pela minha participação em grupo de danças populares, ou mesmo pelos contatos realizados no decorrer dos anos com agremiaçóes e grupos de manifestações populares de outras cidades e estados brasileiros. Desta forma, confirma-se o pensamento de Alves quando a autora escreve que: "A relação pesquisador (a) - pesquisa é tecida por fios de motivaçóes, criatividade, histórias de vida, encontros e desencontros que se revelam numa rede de significados que dão sentido à vida do (a) pesquisador (a) e aos seus estudos" (ALVES, 2006: 15).

Extremamente significativas foram as análises construídas ao longo da pesquisa, no que diz respeito ao aspecto de repensar o papel que as danças ocupam na vida, no cotidiano daqueles (as) que as vivenciam. Outros aspectos ressaltados são o caráter lúdico inerente às mesmas, a possibilidade da expressão da linguagem corporal e o que representam na construção das identidades dos brincantes[11].

\section{Na direção do Departamento de Cultura}

Passados poucos anos de suas viagens, Mário de Andrade foi convidado a ocupar o cargo de diretor do DCSP, pelo seu então amigo Paulo Duarte, que era chefe de gabinete do prefeito Fábio Prado. Além dele, outros intelectuais modernistas assumiram funçóes na gestão que tinha como governador de estado Armando de Salles Oliveira.

Anteriormente, em fins dos anos de 1930, o mesmo grupo de intelectuais modernistas sustentava a ambição de um dia efetivar o táo sonhado projeto de democratização da cultura e da arte, não ficando elas restritas aos grupos privilegiados.. Por isso, a oportunidade que se concretizava deveria ser aproveitada.

O DCSP se estruturou em quatro segmentos, sendo: a Divisão de Bibliotecas, chefiada por Rubens Borba de Morais; a Divisão de Educação e Recreio, chefiada por Nicanor Miranda[12]; a Divisão de Documentação Histórica e Social, dirigida por Sérgio Milliet e a Divisão de Expansão Cultural, também dirigida por Mário de Andrade.

Priorizo no trabalho a apresentação das políticas implementadas pelo seu então diretor, demonstrando o estreito vínculo entre a pesquisa realizada previamente e que agora tinha espaço e condiçôes de açóes de extensão.

Uma das vias encontradas foi a proposta pedagógica instituída nos PIs,[13] embasada no binômio educação-cultura[14], com isso uma das prioridades foi criação de espaços e tempos para a realização de atividades artísticas e culturais, proporcionando às crianças frequentadoras o contato com e a vivência de muitas linguagens. Entre elas estavam as manifestaçôes das culturas populares. Interessou-me mostrar o espaço ocupado pelas danças nas programaçóes, para isso utilizei imagens representativas que foram registradas pelo fotógrafo Benedito 
Figura 1

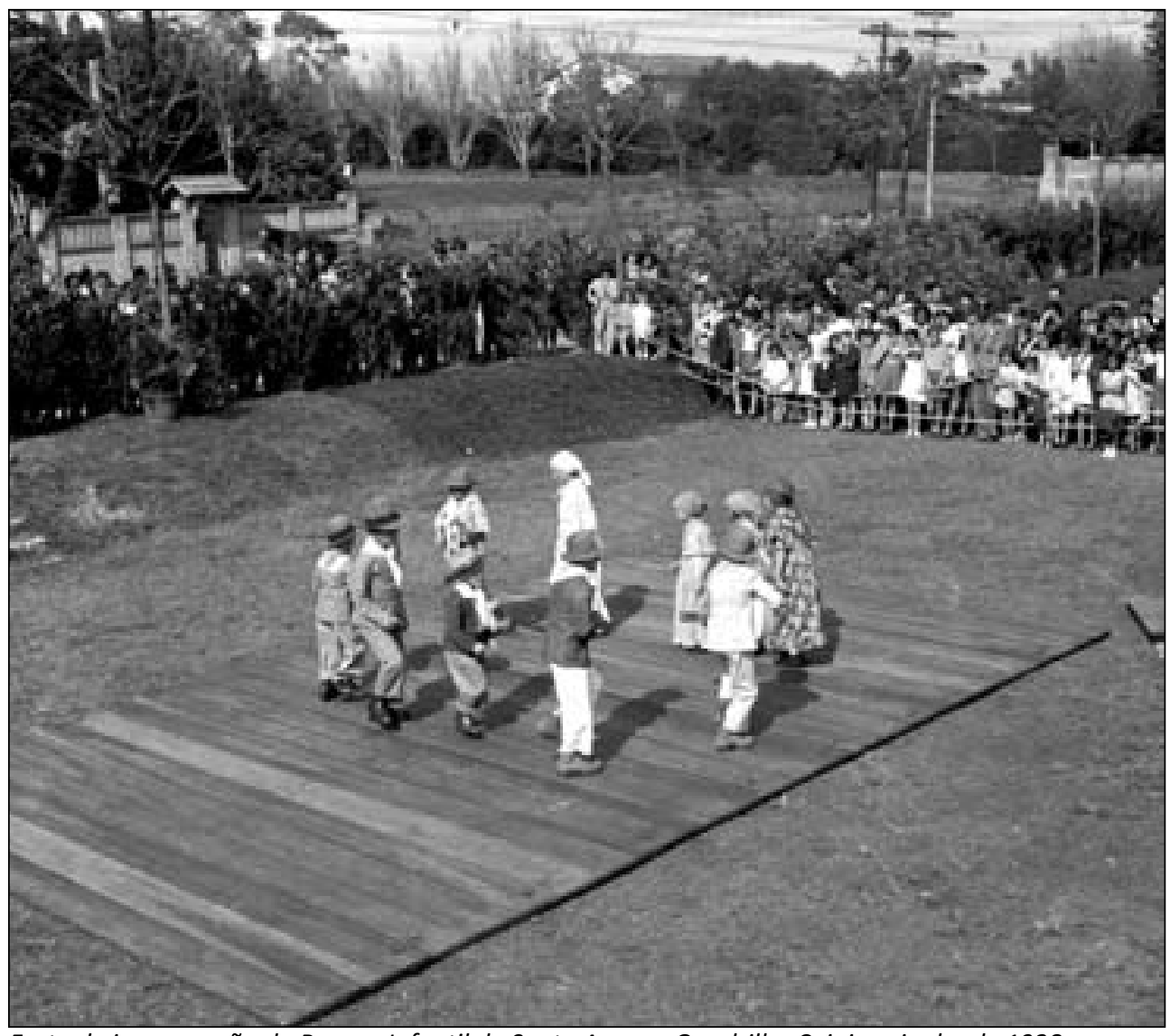

Festa de inauguração do Parque Infantil de Santo Amaro. Quadrilha Caipira - junho de 1938.

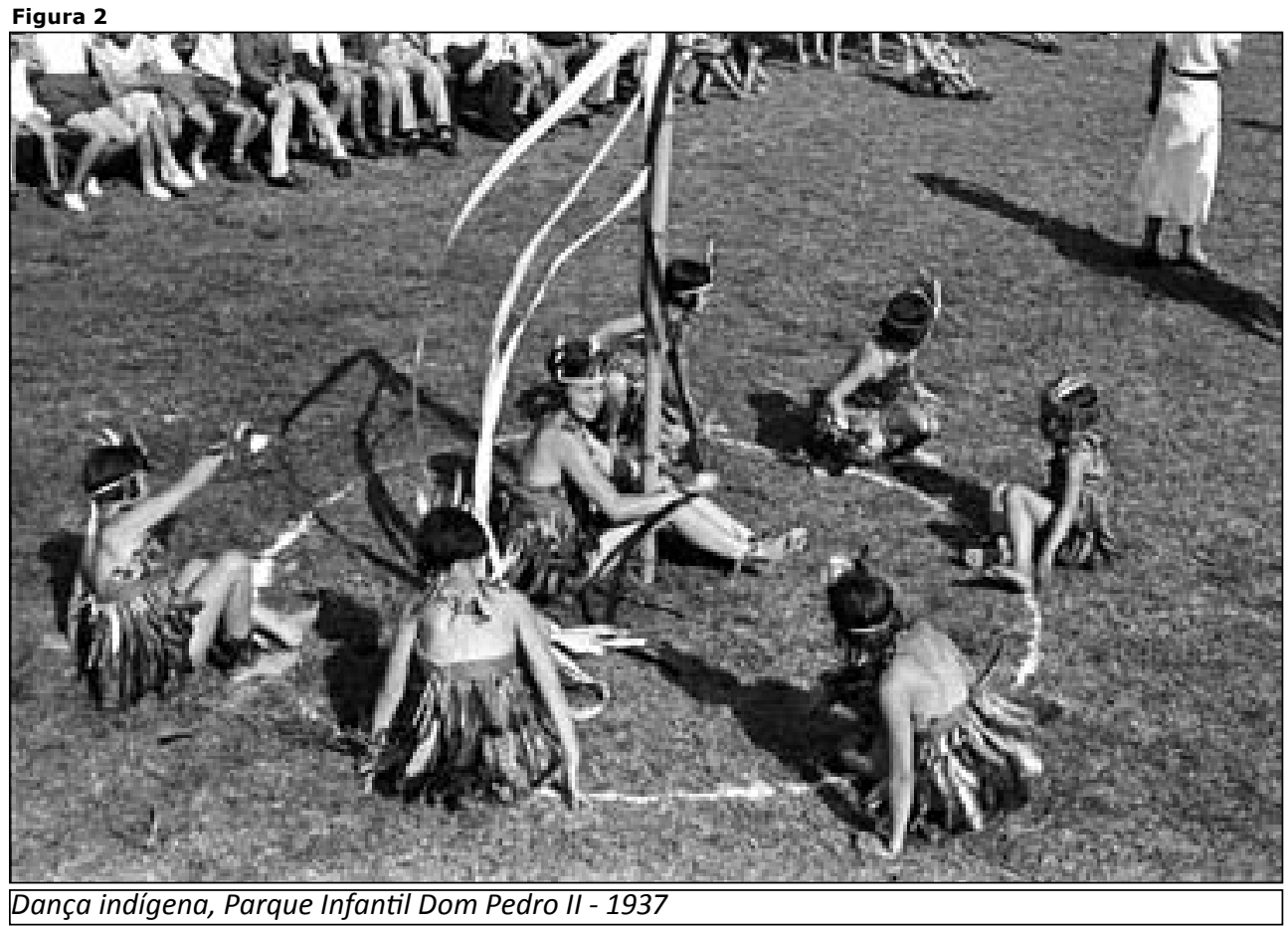

Junqueira Duarte[15] (BJ). [Figs. 1 e 2]

Para Gobbi (2004: 124), no trabalho desenvolvido nos PIs, ficam evidentes os aspectos estéticos e ideológicos que os modernistas objetivavam difundir, visto que:
15 - Os documentos fotográficos dos PIs pertencem ao Acervo da Casa da Imagem do Museu da Cidade de São Paulo (Seção Arquivo de Negativos). 
Nestes espaços, retomar os princípios da Antropofagiainspirando-nos no próprio Manifesto Antropofágico, seria muito bem vindo. Desta forma, numa espécie de banquete, nos fartamos dos desenhos, das festas, das danças, das músicas, e de tantas expressóes destes seres humanos de pouca idade numa brasilidade macunaímica com todos os caráteres de maneira a assegurarmos a manutenção da vida em sua inteireza expressando-se nos grupos compostos por crianças pequenas e pequenininhas, procurando adquirir as virtudes de suas próprias raízes históricas reforçando seu poder, suas ideias, suas propostas, seu ser transbordando-se. [grifos meus]

Ainda no DCSP, Mário de Andrade criou o curso de Etnografia e Folclore, o que surgiu do seu empenho em formar pesquisadores capacitados para o campo das culturas populares; após seus estudos e trabalhos na área, o intelectual avaliava que muito tinha para se descobrir e documentar, no entanto náo havia pessoal preparado para tal exercício. Para a efetivaçáo desse projeto contou com parceria da etnógrafa Dina (Dreyfus) Lévi-Strauss; o curso aconteceu de abril a outubro de 1936 e teve alunos do próprio DCSP, da Universidade de São Paulo e outros interessados.

Foi um curso de extensão universitária, dado no Departamento, com feição eminentemente prática, visando o preparo dos alunos para pesquisa de campo. Metodologia importante, chamando a atenção para as exigências de uma colheita cientificamente documentada, a fim de torná-la confiável para pesquisas e análises posteriores (o local, a função e a descriçáo do documento, dados sobre o informante, etc.). O Curso de Etnografia e Folclore, ministrado em 21 aulas, definia áreas do conhecimento, grupos de objetos e documentos, sua classificação, análise e documentação. Enfocou desde contos, lendas, o folclore musical, até a cultura material ... (BATISTA, 2004: 47)

16 - Também se realizou pesquisas que mais tarde comporiam o terceiro volume de Danças Dramáticas do Brasil (Congadas e Moçambiques).

17 - Cf. ANDRADE, 1937.

18 - Cf. SANTOS, 1937.
Em virtude do sucesso do curso, surgiu a SEF, em abril de 1937, tendo como seu primeiro presidente Mário de Andrade. A Sociedade desenvolveu várias pesquisas e suas publicaçóes davam-se através da Revista do Arquivo Municipal (RAM)[16]. Destaco aqui as relacionadas às danças populares existentes no estado de São Paulo, como o trabalho feito por Mário de Andrade: "O samba rural paulista”[17], e o de Marciano dos Santos: "A dansa de São Gonçalo"[18].

No mesmo ano de fundação, a SEF recebeu o convite, através do DCSP, para participar do Congresso Internacional de Folclore, em Paris. Para isto organizou o mapeamento de danças folclóricas e crendices características do estado.

A pesquisa de mapeamento das danças aconteceu através do envio de questionários aos (às) vários (as) associados (as) da SEF residentes na capital e em municípios do interior do estado, totalizando 244 localidades. Com a devolutiva de 842 questionários, foi feita a tabulação dos dados para assim ocorrer a organi- 
zação dos mapas, que foram apresentados no Congresso por Nicanor Miranda.

Considero de extrema relevância a existência de tal pesquisa que proporciona conhecer quais bailados eram característicos das várias cidades do estado. Devido o grande número de questionários, me detive à leitura somente dos que se referiam ao município de Campinas, por ser a cidade desta pesquisadora, também por ser o que retornou o maior número de documentos[19].

O último e representativo projeto de Mário de Andrade na direção do DCSP foi a coordenação da MPF. Para isso montou uma equipe de quatro pessoas, liderada por Luiz Saia, ex-aluno do curso de Etnografia e sócio da SEF, que viajou por municípios do norte e nordeste incumbida de registrar através de filmes, gravaçôes sonoras, fotografia, cadernetas de campo, o maior número possível de folguedos e manifestaçóes populares; dados dos (as) informantes, e colher objetos relacionados ao tema.[Fig. 3]

A viagem aconteceu no período de fevereiro a julho de 1938, porém, num momento de mudanças no cenário político; Mário de Andrade perdia todo apoio que recebia no Departamento devido à instalaçáo do Estado Novo, como conta Batista (2004, p. 50): “... com a queda do governador e do prefeito, nomeação do interventor Ademar de Barros e, em 9 de maio de 1938, do prefeito Prestes Maiao escritor seria destituído da direçáo do Departamento (11 de maio), afastando-se também, em junho, da chefia da Divisão de Expansão Cultural.

Mário de Andrade deixou o DCSP e mudou-se para o Rio de Janeiro. No mês seguinte a MPF retornou a Sáo Paulo trazendo um vasto material de pesquisa, acervo que hoje pertence à Discoteca Oneida Alvarenga, no CCSP. A concretização da MPF, foi, sem dúvida, a realização do grande sonho desse homem público, educador, poeta, intelectual que tanto almejou aproximar as culturas populares e erudita, pois acreditava que assim se produziria uma cultura que representaria o Brasil.

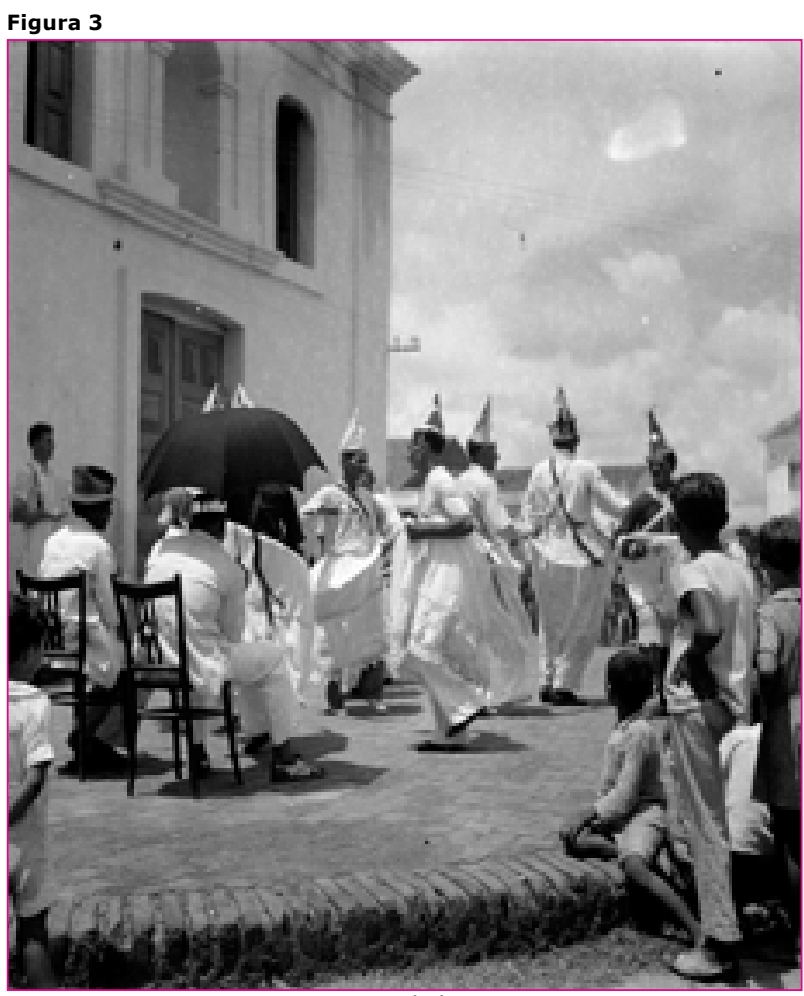

Reis de Congo. Pombal (PB). 11/4/1938. Foto de Luiz Saia.

\section{Diálogos COM A CONTEM- PORANEIDADE}

Uma importante referência para a construção das análises, estabelecendo diálogo com a contemporaneidade, foi o documentário Mário e a missão (2003), dirigido por Luiz Adriano Daminello, que refez o trajeto da MPF de 1938 e registrou as manifestaçóes na atualidade. Observa-se que, apesar das falas dos brincantes, que denuncia a falta de apoio governamental, pouco alização das manifestaçóes, há enorme empenho por parte dos mesmos em dar continuidade às tradiçóes, incentivo e verba para a re-
19 - Campinas foi o município que retornou 32 questioná!@rios, sendo eles respondidos por 27 professoras, 3 médicos, 1 diretor de escola e 1 pessoa a qual o campo da profissão encontra-se ilegivel. As danças assinaladas por mais de $50 \%$ dos entrevistados foram: a valsa (28); polca (26); mazurca (25); quadrilha (22); miudinho (16); samba ou batuque (16). Esses dados foram acessados no acervo da SEF, pertencente ao CCSP. 


\section{Artigos \& Ensaios}

20 - Expressão utilizada por uma das entrevistadas quando falou que mesmo sem ajuda financeira de instituições governamentais a agremiação persiste em manter a manifestação, Rosinete, presidente da Nação do Maracatu Elefante, MÁRIO e a missão (2003). uma vez que essas estáo no sangue[20].

Também na busca de estabelecer novos diálogos, realizei entrevistas com o dois pesquisadores da obra de Mário de Andrade, o diretor do documentário citado acima; Amarildo Carnicel, que refez a segunda viagem etnográfica de Mário de Andrade, nos fins dos anos de 1980, objetivando fazer novos registros fotográficos das imagens documentadas pelo intelectual quando esteve no nordeste entre os anos de 1928-29. Por fim, a mestra de danças populares Raquel Trindade. Seja pelos depoimentos dos pesquisadores, que tiveram contato com o universo das danças pesquisadas por Mário de Andrade, nas últimas décadas, ou ainda da mestra de danças que até hoje desenvolve projetos de extensão no campo das culturas populares, nota-se que houve transformaçóes em vários aspectos. Todavia, as danças continuam povoando espaços e tempos de vários grupos, agremiaçóes, comunidades, se reinventando em vários cantos do Brasil.

Finalizo a dissertação com um texto, em estilo epistolar, para Mário de Andrade, contando sobre as descobertas suscitadas pelo estudo da sua obra, informando-lhe dos mais recentes acontecimentos relacionados à continuidade das manifestaçóes populares e afirmando ao poeta que, ao fim da pesquisa, a sua previsão, registrada pela emblemática frase: "Da maneira como as coisas vão indo, a sentença é de morte", não se concretizou, pois mesmo persistindo as limitaçóes, barreiras, dificuldades para que os brincantes perpetuem suas tradiçóes, há algo que transcende, fazendo com que esses sujeitos persistam em brincar, dançar, cantar e nos encantar com sua arte.

Declaro que:

Com o decorrer da pesquisa realizei outros encontros com as danças; diferente da brincante que há alguns as vivencia, esses novos encontros aconteceram através dos relatos do turista que narrou as sensaçóes e impressóes quando das suas andanças pelo país, que se deparou com tantos outros brincantes, ou ainda, com a leitura de Danças Dramáticas, onde você contextualizou as que foram registradas nos finais dos anos de 1920; ao basear-me no documentário Mário e a missão... percebo o quão atuais e significativas são elas, mesmo admitindo as transformaçôes ocorridas visto que... as culturas não são estáticas. Confesso também que, neste momento, tal pesquisa inspira e possibilita-me maior proximidade para instituir um diálogo com você, poeta, escritor, brincante, político e obstinado pesquisador que se empenhou em mostrar outros Brasis.... Seus registros, publicaçóes e açôes de disseminação das danças populares foram acompanhados por uma grande preocupação com a morte dessas culturas, com isso resultaram na produção de um extenso material que se tornou referência para quem se proponha a aprofundar os conhecimentos sobre esta temática... Saliento que recolho do passado, para olhar as danças no presente, a capacidade de ressignificação das identidades dos sujeitos, pois ao realizarem essas manifestaçôes artísticas são eles (as) 
que passam a serem os (as) protagonistas, se permitindo comunicarem ludicamente... Transformam-se em reis, rainhas, caboclos, guerreiros, palhaços, juízes, mestres, mestras, e tantas outras personagens existentes em nossas danças... os encontros com as danças através da sua obra são inspiradores para se alargar os conhecimentos relacionados a essas manifestaçôes populares. Hoje, muito mais que antes, sinto-me instigada a dividir saberes adquiridos através das minhas vivências e aqueles acessados depois deste nosso encontro... Teria muito, mas muito mesmo, o que compartilhar, mas por ora vou encerrando... (PAULA, 2012, p. 166-175)

Felizmente podendo dizer: Viva a dança, dança viva![25]

Porque muitos (as) de nós continuamos na dança!

\section{REFERÊNCIAS BIBLIOGRÁFICAS}

ALVES, Teodora de Araújo. Herdanças de Corpos Brincantes: Os Saberes da Corporeidade em Danças Afro-brasileiras. Natal, RN: Editora da UFRN, 2006.

ANDRADE, Mário de. "O samba rural paulista”. RAM, ano IV, vol. XLI, nov/1937a, p.37-116.

. Mário de. Poesias Completas. 3aed. São Paulo: Livraria Martins Editora S.A.; Brasília, INL, 1972.

- O Turista Aprendiz. Estabelecimento de Texto, Introdução e Notas de Telê Porto Ancona Lopez. São Paulo, Duas Cidades, Secretaria da Cultura, Ciência e Tecnologia, 1976.

- Danças Dramáticas do Brasil. Edição Organizada por Oneyda Alvarenga. 2a Edição. Belo Horizonte: Editora Itatiaia, 1982a, vol. 1.

- Danças Dramáticas do Brasil. Edição organizada por Oneyda Alvarenga. 2a Edição. Belo Horizonte: Editora Itatiaia, 1982b, vol. 2.

Danças Dramáticas do Brasil. Ediçáo organizada por Oneyda Alvarenga. 2a Edição. Belo Horizonte: Editora Itatiaia, 1982c, vol.3.

BAKHTIN, Mikhail M. A Cultura Popular na Idade Média e no Renascimento: O Contexto de François Rabelais. São Paulo: Hucitec; Brasília: Editora da Universidade de Brasília, 1999. $4^{\mathrm{a}}$ ed.

BATISTA, Marta Rossetti (org). Coleção Mário de Andrade: Religião e Magia; Música e Dança; Cotidiano. São Paulo: Editora da Universidade de São Paulo; Imprensa Oficial do Estado de Sáo Paulo, 2004- (Uspiana: Brasil 500 anos).

BENJAMIN, Roberto E. C. Folguedos e Danças de Pernambuco. 2a ed. Recife: PCR, 1989.

CARNICEL, Amarildo. O Fotógrafo Mário de Andrade. 2a ed. Campinas, SP: Editora da Unicamp, 1994.

CONRADO, Amélia V. S. "Danças populares brasileiras.Valor educacional, cultural e recurso para pesquisa e recriação cênica”. Secretaria de Cultura. Fundação Cultural do Estado da Bahia, 2004. Disponível em: http://www. fundacaocultural.ba.gov.br/04/revista $\% 20 \mathrm{da} \% 20 \mathrm{bahia} /$ Folguedos/dancas. htm Acesso em 25/10/2011.

GOBBI, Márcia A. "Desenhos de outrora, desenhos de agora: os desenhos das

25 - Verso do poema Danças, de Mário de Andrade, escrito em 1924, cf. ANDRADE, 1972. 
crianças pequenas no acervo de Mário de Andrade”. Tese de doutorado. Faculdade de Educação, Universidade Estadual de Campinas, Campinas, 2004.

HUIZINGA, Johan. Homo Ludens: O Jogo como Elemento da Cultura.Sáo Paulo: Perspectiva/ Editora da USP, 1971.

LOPEZ, Telê Porto Ancona. Mário de Andrade: Ramais e Caminho. SP: Livraria Duas Cidades, 1972.

PAULA, Roberta Cristina de. "Quem foi que disse que não vivo satisfeito? Eu danço! Encontros com as danças na obra de Mário de Andrade”. Dissertação de mestrado. Faculdade de Educação, Universidade Estadual de Campinas, Campinas, 2012.

RAFFAINI, Patrícia Tavares. Esculpindo a Cultura na Forma Brasil: o Departamento de Cultura de São Paulo (1935-1938). São Paulo: Humanitas/FFLCH/ USP, 2001.

SANTOS, Eleonora Campos da Motta. "A expressão danças dramáticas em textos acadêmicos." VI Congresso de Pesquisa e pós-graduação em artes cênicas". 2010. Disponível em: < http://www.portalabrace.org/vicongresso/pesquisadanca/Eleonora $\% 20$ Campos $\% 20 \mathrm{da} \% 20$ Motta $\% 20$ Santos $\% 20$ express\%E30\%20dan\%E7as\%20dram\%E1ticas\%20em\%20textos\%20 acad\%EAmicos.pdf> Acesso em: 18/07/2011.

SANTOS, Marciano dos. "A dansa de São Gonçalo”. RAM, ano III, vol. XXXIII, março/1937, p.85-116.

Filmografia

MÁRIO e a missão. Direção, roteiro e pesquisa: Luiz Adriano Daminello. Produção executiva: Jorge Palmari. Trombeta Produtora de Imagens, Rede STV, Fapesp, Labjor e Instituto Uniemp, 2003. 